\title{
COMPARATIVE ANALYSES OF NON-MARINE OSTRACODS (CRUSTACEA) AMONG WATER BASINS IN TURKEY
}

\author{
Mehmet Yavuzatmaca \\ Department of Biology, Faculty of Arts and Science, Bolu Abant İzet Baysal University, Turkey \\ E-mail: yavuzatmaca46@gmail.com; https://orcid.org/0000-0002-0398-6763
}

Total of 26, 22 and 32 sites in Konya, Antalya and West Mediterranean basins in Turkey, respectively, were sampled twice during 2017 to compare the non-marine ostracod diversity. A total of 1787 individuals belonging to 31 species were recorded from all basins. Of which, nine species are common among basins when Fabaeformiscandona fragilis is new for Turkey. High species diversity was found at middle elevational intervals. The highest and lowest Shannon diversity index values were recorded for both Konya $(\mathrm{H}=2.19)$ and Antalya $(H=1.90)$ basins, respectively. The highest beta diversities values are encountered between closed the Konya and other open basins. Species and environmental variables composition among basins and elevational intervals showed significant differences ( $p<0.05$, ANOSIM). Of species, cosmopolitans (e.g., Candona neglecta, Ilyocypris bradyi, Psychrodromus olivaceus) provide an important contribution to the differences in diversities among basins and elevational intervals. According to Canonical Correspondence Analysis, elevation appeared to be the common influential variables in all basins. Results suggest that alpha diversity is under the control of local and regional factors when beta diversity is primarily affected by regional factor. Although cosmopolitan species are positive indicators, they seem to make a significant contribution to alpha and beta diversities of ostracods.

Keywords: basins, alpha and beta diversity, elevation, cosmopolitan, Ostracoda.

\section{INTRODUCTION}

Non-marine ecosystems are altered by natural (e.g., the climatic changes, geologic factors) and anthropogenic activities. Of which, human-mediated deteriorations are irreversible influences on the characteristics of freshwater (or non-marine) habitats by sediment loading, organic pollution, toxic contaminants, habitat fragmentation, flow regulation (especially by dam construction), and introducing of non-indigenous species (RICCIARDI \& RASMUSSEN 1999, SøNDERGAARD \& JePPESEN 2007, StRAYER \& Dudgeon 2010). Such influences on water bodies indicate a requirement of water management for long-term ecological sustainability. In order to deal with such problems and provide possible solutions caused by human activities, European Water Framework Directive has introduced water management policy for all of the European countries for the chemical and ecological quality of freshwaters in the year of 2000. Ecological quality is evaluated according to biological, hydro-morphological and physico-chemical composition of water bodies. Biological quality includes the composition and abundance of benthic invertebrates, fish and flora. In this 
protection policy, geographical and hydrological units are used instead of administrative or political boundaries targeting to protect water as a single system like a river basin (EuRopean CoMmission 2018). A river or lake basin is an entire geographical area that is drained by a river and its tributaries. Therefore, the species diversity (or richness) in the different aquatic habitats in the river catchment or basin has a crucial role for the conservation of biodiversity (ENGEN et al. 2008) and for the development of management to conserve status of aquatic systems. Besides to the conservation importance of diversity, such knowledge can improve our understanding on the evolutionary and ecological succession of species in different types of habitats (WhITTAKER 1972, Hill 1973, Giвв et al. 2013, KüLKÖYLÜOĞLU et al. 2017a).

The number of species per unit area is indicated as the species diversity or richness while biological diversity includes functional group diversity, number of trophic levels and species abundance (Brown et al. 2007). Species diversity is measured as gamma $(\gamma)$ diversity (regional diversity) that is composed of alpha ( $\alpha$, local diversity) and beta ( $\beta$, changes in species diversity from one site/region to next) diversities (WhitTAKER 1972). While regional diversity is represented by various habitats and conditions, local diversity includes one habitat (e.g., lake, creek). Therefore, regional and local species pools can be defined as the subset of $\gamma$ and $\alpha$ diversities, respectively (P̈̈rTEL et al. 1996). Some species in regional species pool may not be encountered in the local species pool as a result of dispersal limitation but this limitation has little effect on the presence of a species in local species pool to being in another site (Brown et al. 2007). Along with dispersal limitation, biotic and abiotic factors can alter the species composition between local sites or regional sites (Zoвel et al. 1998). Thereby, $\beta$ diversity depends on the dispersal ability and ecological tolerances of species.

Ostracods are tiny $(0.3-5 \mathrm{~mm}$ long) bivalved benthic invertebrates. They show wide distributions in a variety of marine and non-marine habitats (МеIsch 2000). Active and/or passive dispersal abilities of species contribute to their wide geographical distribution in the world (McKenzie \& Moroni 1986, Rodriguez-Lazaro \& Ruiz-Muñoz 2012, Valls et al. 2016). They display quick response to environmental changes because of a short reproductive cycle (Delorme 1991) that allows them to be used as bio-indicator species to evaluate habitat conditions of different aquatic bodies (KüLKÖYLÜOĞLU 2013). Their carapaces with low magnesium calcites are easily fossilized in the sediments that is why they are to be found as fossil forms in rock formations since Early Ordovician (ca. 485 million years old) (Williams et al. 2008). Therefore, ostracods are widely applied in recent marine and non-marine environmental research and also for stratigraphic and palaeoecological purposes (RoDRIGUEZLAZARo \& Ruiz-MuÑoz 2012). In this sense, the distributional pattern and eco- 
logical information of ostracod species have vital roles to make better and strong inferences about the recent and past status of aquatic bodies.

Until now, 145 non-marine ostracod species have been known from Turkey (KüLKÖYLÜOĞLU et al. 2015, KüLKÖYLÜOĞLU et al. in review, YAvUZATMACA et al. 2017b). However, this number is believed to be underestimated and the richness is far above it (KüLKÖYLÜOĞLU pers. comm.). The existing studies on the recent non-marine ostracods in Turkey are so far based on ostracod species diversity, distribution, abundance and ecology in a region (or province, includes many habitats) or in a single habitat (includes monthly and/or seasonal samplings) (e.g., Aкdemir 2008, Акdemir et al. 2016, Altinsaçli \& Mezquita 2008, KüLKÖYLÜOĞLU 2004, KüLKÖYLÜOĞLU et al. 2013, KüLKÖYLÜOĞLU et al. 2012a, 2012b, ÖzuluĞ 2011, UçaK et al. 2014, YavuzatmaCa et al. 2017a). On the other hand, a few studies have included samplings from more than one region or provinces (e.g., Altinsaçli 2004, GüLEN 1985, KüLKÖYlüOĞLU et al. 2017b, c, RAsouli et al. 2014). Although 25 large water basins are present in Turkey (TRMEU 2017-2023), there is no comparative study dealing with the diversity and ecology of ostracods among the basins. Gülen and Altinsaçli (1999) is the only basin-related ostracod study in Turkey but only the ostracod fauna of Sakarya River basin was given. This present situation is pinpoint the importance of the current study in terms of comparing ostracod diversity among three river basins for the first time in Turkey. The main aim of the study is to compare species diversity and ecological preferences of ostracods in Konya, Antalya, and West-Mediterranean river basins in Turkey. Also, a classification of the lotic and lentic habitats due to the elevation has been used by The Water Management Directorate Department of Turkish Republic Ministry of Agriculture and Forestry. In this classification, three elevational intervals like $0-800,800-1600$ and $>1600 \mathrm{~m}$ a.s.l. have been used. The effect of elevation on ostracods is an ongoing discussion in the literature (e.g., Guo et al. 2013, KüLKÖYLÜOĞLU et al. 2012a, 2012b, KüLKÖYLÜOĞLU et al. 2016, LAPRIDA et al. 2006, Mezquita et al. 1999, Pieri et al. 2009, Yavuzatmaca et al. 2018). Therefore, comparison of dis/similarity values for species and/or environmental variables among the elevational intervals mentioned above is one of the important point of this study.

\section{MATERIAL AND METHODS}

\section{Study sites}

Konya basin. According to the natural topography, Konya basin does not drain its waters into the sea. Similar topography is rare and known in a few areas in the world, such as that Great Basin area in Nevada. The importance of such basins is that the water is born and lost in the area within which it can only be used by the organism inhabiting the area. 
In terms of Konya basin, it is the only known closed basin in the Central Anatolia Region of Turkey. The basin has about $49805 \mathrm{~km}^{2}$ of surface area including nine provinces $(85 \%$ of Aksaray, $73 \%$ of Konya, $60 \%$ of Karaman, $31 \%$ of Niğde, $14 \%$ of Isparta, $12 \%$ of Nevşehir, $7 \%$ of Ankara, $2 \%$ of Mersin and 2\% of Antalya) covering ca 7\% of Turkey (Trmfwm 2016, Trmeu 2017-2023).

Antalya basin. Antalya basin is present in the Mediterranean region of Turkey and its waters are discharged into the Mediterranean Sea. The surface area of the basin is ca. 20331 $\mathrm{km}^{2}$ consisting about $3 \%$ of the surface area of Turkey. The basin is one of the richest regions of Turkey in terms of water resources (ТRмғwм 2016). It harbors 52\% of Antalya, 30\% of Isparta and 18\% of Burdur provinces within its boundaries (TRMEU 2017-2023).

West Mediterranean basin. The basin covering about $3.1 \%$ of the Turkey with about $21223 \mathrm{~km}^{2}$ of surface area is located in the West Mediterranean region of Anatolia and its water is released into the Mediterranean and Aegean Seas (ТRмғwм 2016). This includes five provinces (80\% of Muğla, 33\% of Antalya, $21.8 \%$ of Denizli, $21.1 \%$ of Burdur and $0.3 \%$ of Aydın provinces) (TRMEU 2017-2023).

\section{Samplings}

A total of 26 (11 lakes and 15 creeks), 22 (5 lakes and 17 creeks) and 32 (13 lakes and 19 creeks) aquatic sites of natural lakes and creeks were sampled twice during August and October of 2017 in Konya, Antalya and West Mediterranean basins in Turkey, respectively (Fig. 1). All ecological variables were measured before sampling to reduce disturbance on the measurements. Among them, dissolved oxygen concentration ( $\mathrm{DO}, \mathrm{mg} / \mathrm{L})$, water temperature $\left(\mathrm{Tw},{ }^{\circ} \mathrm{C}\right)$, electrical conductivity $(\mathrm{EC}, \mu \mathrm{S} / \mathrm{cm}), \mathrm{pH}$ and salinity $(\%$ o) of water were recorded with a YSI-Professional Plus and a GARMIN etrex Vista H GPS was used to obtain geographical data (elevation, coordinates (for constructing the map, Fig. 1)). The

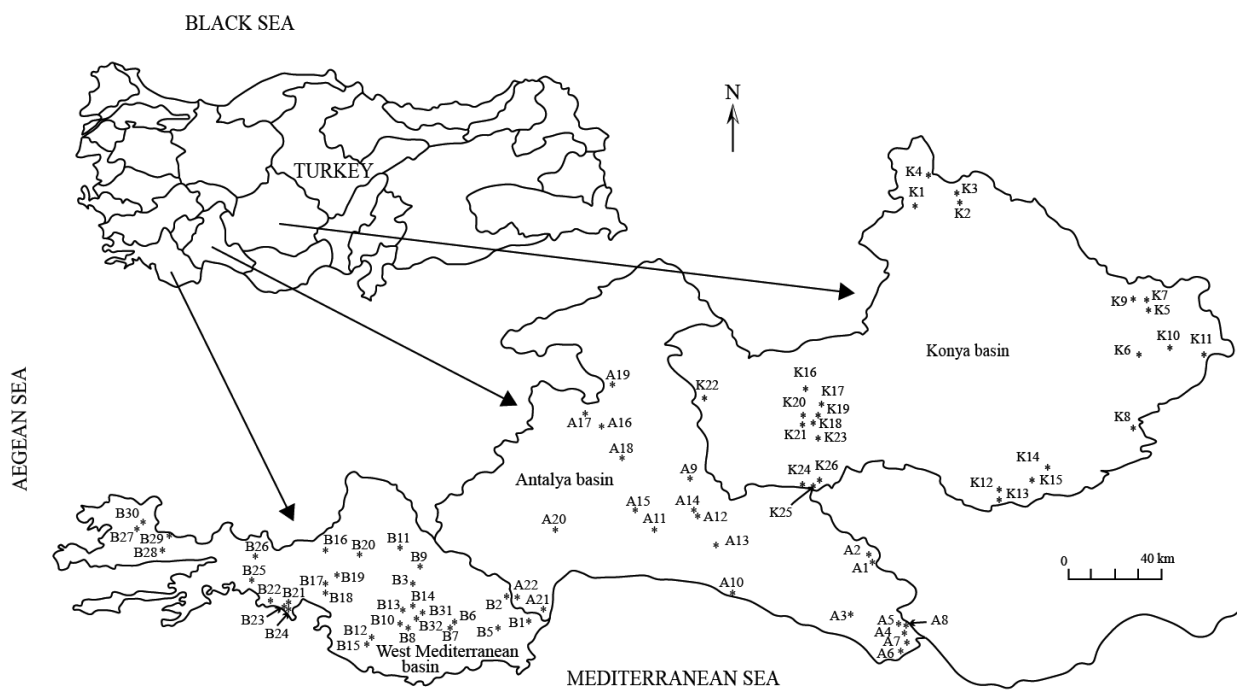

Fig. 1. Sampling sites in Konya (K), Antalya (A) and West Mediterranean (B) basins 
minimum-maximum and mean values of ecological variables for basins and each species are given in Table S1.

A standard sized hand net ( $200 \mu \mathrm{m}$ in mesh size) was used to collect ostracod samples from the sediment throughout littoral zones of lakes and the parts of creeks with slow flow regimes with a maximum of $1 \mathrm{~m}$ depth. Sediment samples were anchorage with $70 \%$ of ethanol in $250 \mathrm{ml}$ plastic bottles in situ to preserve ostracod specimens from decay. In the laboratory, sediments including ostracods were filtered through four standardized sieves $(0.5,1.0,1.5$ and $2.0 \mathrm{~mm}$ mesh size) under tap water to separate coarse materials and then filtered sediments were collected in $250 \mathrm{ml}$ plastic bottles with added $70 \%$ ethanol. Subsequently, ostracods were separated from the sediments under a stereomicroscope (Olympus $\mathrm{ACH} 1 \mathrm{X}$ ) by using a pipette and dissecting needles. Dissected soft body parts in lactophenol solution and carapace morphology were accomplished under a light microscope (Olympus BX-51) for the identification of specimens to species and genus level according to Meisch (2000). Ostracod samples are kept at the Limnology Laboratory of Bolu Abant İzzet Baysal University, Turkey.

\section{Statistical analyses}

Shannon index values were calculated for each basins and elevational intervals by Species Diversity \& Richness 4 software (SEAby \& Henderson 2006). This software was also used to estimate Whittaker's beta ( $\beta$ ) diversity index values (Wilson \& SHMIDA 1984) for all and dual comparisons of basins and elevational intervals as well. Differences in ostracod communities and environmental variables, and contribution of individual species and environmental variables to any of dissimilarities among the basins and elevational intervals were checked out by Analysis of similarity (ANOSIM) and Similarity percentages (SIMPER), respectively (Community Analysis Package 4 software). In addition, whether there is a significant difference in the mean of ecological variables among the basins and elevational intervals that were tested by One-Way ANOVA (IBM-SPSS Statistics Version 21). The Levene's test and Kolmogorov Smirnov (if $n>50$ ) or Shapiro-Wilk $(n<50)$ tests affirmed the homogeneity of variance and data normality assumption, respectively. If assumptions are not met, non-parametric Kruskal-Wallis was applied. Post-hoc analyses were conducted to see possible significance. Elevational intervals like 0-800 (E1), 800-1600 (E2) and $>1600$ (E3) $\mathrm{m}$ a.s.l. was used in the analysis and these intervals are showed hereafter by the abbreviations in brackets. Detrended Correspondence Analysis (DCA) was used to check out the suitability of data for Canonical Correspondence Analysis (CCA). Most effective ecological variables on species composition in each basin were determined by CCA using the CANOCO 4.5 software (TER BRAAK 1986). Cyrideis torosa is susceptible to salinity (or occur in high saline waters) and so it has been excluded from the CCA analysis to prevent a conditional result (see Discussion). In CCA, species appeared at least two times were used. Monte Carlo permutation test (499 permutations) was performed to see the effectiveness of variables. Meaningful correlations between species encountered at least three times and used environmental variables were tested by a non-parametric Spearmen Rank Correlation analyses (IBM-SPSS Statistics Version 21). The optimum $\left(u_{\mathrm{k}}\right)$ and tolerance $\left(t_{\mathrm{k}}\right)$ levels of the species occurred three or more times during the study were calculated by $\mathrm{C} 2$ software (JuGGINs 2003). Specimens with damaged soft body parts and carapaces were omitted from the analyses and only undamaged adult individuals are used. 


\section{RESULTS}

A total of 1787 individuals belonging to 31 ostracod species (gamma $(\gamma)$ diversity) were recorded from Konya (21 species (spp.), 453 individuals (ind.) from 21 sites), Antalya (15 spp., 401 ind. from 15 sites) and West-Mediterranean basins (21 spp., 933 ind. from 23 sites) (Table 1). Nine species (Candona neglecta, Heterocypris incongruens, Ilyocypris bradyi, Potamocypris similis, P. fallax, Physocypria kraepelini, Prionocypris zenkeri, Pseudocandona albicans and Psychrodromus olivaceus) were found to be common to the three basins (Table 1). Moreover, Konya and Antalya basins showed both the highest $(\mathrm{H}=2.19)$ and the lowest $(\mathrm{H}=1.90)$ Shannon index (alpha, $\alpha)$ values, respectively (Table 2$)$. Among the species, bisexual populations of Candona sanociensis ( 1 t and 1 t

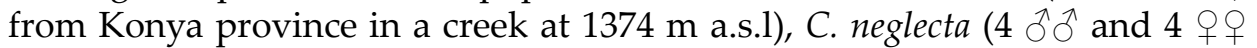
from Konya province in a creek at $1622 \mathrm{~m}$ a.s.l.), C. weltneri $(3 \hat{\delta} \widehat{\delta}$ and 18 우우 from Konya province in a lake at $1849 \mathrm{~m}$ a.s.l.), Cypria ophtalmica (1 $\widehat{\delta}$ from Aksaray province in a lake at $1173 \mathrm{~m}$ a.s.l.) and I. bradyi $(1$ ond 2 o 9 from Karaman province in a creek at $1352 \mathrm{~m}$ a.s.l.) were also found in Konya basin. In the West-Mediterranean basin, bisexual populations of Candona angulata (4

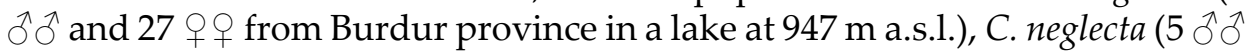
and 22 우 $ᄋ$ from Muğla province in a lake at $1736 \mathrm{~m}$ a.s.l.), Fabaeformiscandona fragilis ( $1 \hat{\jmath}$ from Muğla province in a lake at $223 \mathrm{~m}$ a.s.l.), F. holzkampfi $(1 \hat{\jmath}$ from Muğla province in a lake at $1735 \mathrm{~m}$ a.s.l.), Ilyocypris monstrifica ( 1 o from Denizli province in a creek at $987 \mathrm{~m}$ a.s.l.) and P. olivaceus $(1 \hat{\gamma}$ and 1 f from Muğla province in a creek at $568 \mathrm{~m}$ a.s.l.) were found while there were no bisexual populations in Antalya basin.

The highest species number (25 spp.) was observed at E2 (includes 23 sites (6 lakes and 17 creeks) and 38 samplings (6 from Antalya, 13 from WestMediterranean (West-Med.) and 19 from Konya basins) when the E1 (includes 23 sites ( 7 lakes and 16 creeks) and 33 samplings (16 from Antalya and 17 from West-Med. basins)) and E3 (includes 14 sites (10 lakes and 4 creeks) and 20 samplings ( 2 from Antalya, 5 from West-Med. and 13 from Konya basins)) intervals had 19 and 16 spp., respectively (Table 1). Accordingly, the foremost Shannon index value $(\mathrm{H}=2.15)$ was registered in mid interval when the index value tended to decrease in low $(\mathrm{H}=1.54)$ and high $(\mathrm{H}=1.93)$ intervals (Table 2).

Beta $(\beta)$ diversity values among basins and elevational intervals were given in Table 2 . According to dual comparisons, the supreme $\beta$ diversity values are 0.4444 for Konya - Antalya basins and 0.4146 for E2-E3 intervals (see Table 2).

ANOSIM exhibited significant differences $(\mathrm{p}<0.05)$ in species composition among basins and elevational intervals. According to pairwise comparison, Antalya and Konya basins were significantly different from each other $(\mathrm{p}<0.05)$ while Antalya-West Mediterranean and Konya-West Mediterranean 
Table 1. Species and their abundance (or the number of specimens per species, values in the table) in August (Au) and October (Oc) of 2017 from Konya, Antalya and West-Mediterranean (W Med.) basins and in different elevational intervals (E1 (0-800); E2 (800-1600) and E3 (>1600)). Species names in bold refers to cosmopolitan distribution.

\begin{tabular}{|c|c|c|c|c|c|c|c|c|c|c|c|c|}
\hline \multirow[b]{3}{*}{ Species } & \multicolumn{6}{|c|}{ Basins } & \multicolumn{6}{|c|}{ Elevational Interval (m a.s.l.) } \\
\hline & \multicolumn{2}{|c|}{ Konya } & \multicolumn{2}{|c|}{ Antalya } & \multicolumn{2}{|c|}{ W Med. } & \multicolumn{2}{|c|}{ E1 } & \multicolumn{2}{|c|}{ E2 } & \multicolumn{2}{|c|}{ E3 } \\
\hline & $A u$ & $O c$ & $A u$ & Oc & $A u$ & Oc & $A u$ & Oc & $A u$ & Oc & $A u$ & Oc \\
\hline Candona angulata & & & & 2 & 15 & 31 & & 2 & & 31 & 15 & \\
\hline Candona improvisa & 5 & 12 & & & & & & & 5 & 12 & & \\
\hline Candona neglecta & 18 & 57 & 1 & 2 & 21 & 35 & 1 & 2 & 16 & 17 & 23 & 75 \\
\hline Candona sanociensis & 2 & 3 & & & & & & & 2 & 3 & & \\
\hline Candona weltneri & 8 & 24 & & & & & & & & & 8 & 24 \\
\hline Cypria ophtalmica & & 2 & & & & & & & & 2 & & \\
\hline Cyprideis torosa & & & & & 115 & 213 & 115 & 213 & & & & \\
\hline Cypris pubera & & & 53 & & & & & & & & 53 & \\
\hline Cypridopsis vidua & 2 & 1 & & & 3 & 1 & 2 & & & 1 & 3 & 1 \\
\hline Darwinula stevensoni & & & 10 & 3 & 6 & 3 & 9 & 1 & 5 & 5 & 2 & \\
\hline Fabaeformiscandona fabaeformis & 1 & 1 & & & & & & & & 1 & 1 & \\
\hline Fabaeformiscandona fragilis & & & & & & 1 & & 1 & & & & \\
\hline Fabaeformiscandona holzkampfi & & & & & 5 & 1 & & & 1 & & 4 & 1 \\
\hline Herpetocypris chevreuxi & & & 4 & & & 11 & & 11 & & & 4 & \\
\hline Herpetocypris reptans & & & & & 2 & 8 & & & 2 & 8 & & \\
\hline Heterocypris incongruens & 7 & 6 & 152 & & 7 & 2 & 7 & 2 & 9 & 6 & 150 & \\
\hline Heterocypris salina & 19 & 1 & & & 2 & 2 & 2 & & 19 & 3 & & \\
\hline Ilyocypris bradyi & 20 & 121 & 9 & 5 & 23 & 101 & 11 & 7 & 41 & 206 & & 14 \\
\hline Ilyocypris monstrifica & 2 & & & & 1 & 3 & & & 3 & 3 & & \\
\hline Limnocythere inopinata & & & & & 13 & 22 & & 4 & 13 & 18 & & \\
\hline Paracandona euplectella & 1 & 1 & & & & & & & 1 & 1 & & \\
\hline Physocypria kraepelini & 1 & 3 & 3 & & 15 & 33 & 1 & & 4 & 30 & 14 & 6 \\
\hline Potamocypris fallax & & 9 & & 1 & 1 & 1 & 1 & 1 & & 1 & & 9 \\
\hline Potamocypris similis & & 33 & 21 & 66 & 63 & 13 & 21 & 66 & 63 & 46 & & \\
\hline Potamocypris unicaudata & 7 & 1 & & & & & & & 7 & 1 & & \\
\hline Potamocypris variegata & & & 19 & & 9 & 21 & 22 & 18 & 6 & 3 & & \\
\hline Prionocypris zenkeri & & 4 & 6 & 7 & 1 & & 6 & 7 & 1 & 4 & & \\
\hline Pseudocandona albicans & 5 & & 1 & & 1 & 1 & 1 & & 4 & 1 & 2 & \\
\hline Psychrodromus olivaceus & 19 & 55 & 14 & 12 & 53 & 74 & 8 & 5 & 76 & 129 & 2 & 7 \\
\hline Psychrodromus fontinalis & & 1 & & & & & & & & & & 1 \\
\hline Trajancypris clavata & 1 & & 10 & & & & 10 & & 1 & & & \\
\hline Total & 118 & 335 & 303 & 98 & 356 & 577 & 217 & 340 & 279 & 532 & 281 & 138 \\
\hline
\end{tabular}


Table 2. Shannon index $(\mathrm{H})$ and beta $(\beta)$ diversity values for basins and elevational intervals (E1 (0-800); E2 (800-1600) and E3 (>1600)). vs represents versus.

\begin{tabular}{lcccccc}
\hline & \multicolumn{3}{c}{ Shannon index } & $\begin{array}{c}\beta \text { di- } \\
\text { versity }\end{array}$ & Dual comparisons & $\beta$ di- \\
Sample & $\mathrm{H}$ & Variance H & Exp H & & Sample & \\
\hline Konya & 2.19 & 0.0027 & 8.90 & 0.63 & Konya vs Antalya & 0.4444 \\
Antalya & 1.90 & 0.0028 & 6.66 & & Konya vs W Med. & 0.4286 \\
W Med. & 2.15 & 0.0013 & 8.58 & & Antalya vs & 0.2778 \\
& & & & & W Med. & \\
\hline E1 & 1.54 & 0.0036 & 4.69 & 0.55 & E1 vs E2 & 0.2727 \\
E2 & 2.15 & 0.0018 & 8.59 & & E2 vs E3 & 0.4146 \\
E3 & 1.93 & 0.0028 & 6.89 & & E1 vs E3 & 0.3714 \\
\hline All Sample Index & 2.58 & & & & & \\
Jackknife Std Error & 0.06 & & & & & \\
\hline
\end{tabular}

binary comparisons did not display significant differences ( $p>0.05)$. SIMPER expressed 96.03, 95.68 and $94.59 \%$ of average dissimilarity between AntalyaKonya, Antalya-West Mediterranean and Konya-West-Mediterranean basins groups, respectively. For example, I. bradyi $(15.33 \%)$, P. olivaceus $(13.72 \%)$ and C. neglecta $(10.14 \%)$ are the first three species with high percentage contribution to the dissimilarity between the Antalya and Konya basins (see Table 3). Unlike basins, species composition between all couple elevational interval groups showed significant differences (ANOSIM, $\mathrm{p}<0.05$ ). SIMPER showed 97.82, 96.33 and $95.41 \%$ dissimilarity in the species composition between E1E3, E2-E3 and E1-E2 intervals, respectively. Candona neglecta is the species contributing to the dissimilarities of E1-E3 and E2-E3 intervals with highest percentages as 24.03 and $19.51 \%$, respectively. Similarly, I. bradyi provides about $22.63 \%$ dissimilarity between E1 and E2 intervals (for more see Table 3).

Like species composition, significant differences were also estimated in the composition of the environmental variables among basins and elevational intervals (ANOSIM, $\mathrm{p}<0.05$ ). Composition of the environmental variables in the Konya basin with Antalya and West Mediterranean basins are significantly different $(p<0.05)$. All of the dual comparisons among elevational intervals showed significant differences based on environmental variables $(p<0.05)$. According to SIMPER, elevation and electrical conductivity supply 53.23 and $46.30 \%$ to $45.71 \%$ dissimilarities between Antalya and West Mediterranean basins; 70.22 and $29.43 \%$ to $47.69 \%$ dissimilarities between Antalya and Konya basins; 56.70 and $42.86 \%$ to $42.71 \%$ dissimilarities between Konya and WestMediterranean basins, respectively. Electrical conductivity is the only variable that promotes the dissimilarities between E1-E2 (32.23\% dissimilarity), E1-E3 
Table 3. Contributions of individual species to dissimilarities among basins and elevational intervals. Abbreviations: W Med., West Mediterranean and \%CoDs, \% contribution to dissimilarity, E1 $=0-800 \mathrm{~m}$; E2 $=800-1600 \mathrm{~m}$ and E3 $>1600 \mathrm{~m}$ a.s.l.

\begin{tabular}{|c|c|c|c|c|c|c|}
\hline & \multicolumn{3}{|c|}{ Basins } & \multicolumn{3}{|c|}{ Elevational intervals } \\
\hline & $\begin{array}{l}\text { Antalya- } \\
\text { Konya }\end{array}$ & $\begin{array}{l}\text { Antalya- } \\
\text { W Med. }\end{array}$ & $\begin{array}{l}\text { Konya- } \\
\text { W Med. }\end{array}$ & E1-E2 & E1-E3 & E2-E3 \\
\hline Species & $\%$ CoDs & $\%$ CoDs & $\%$ CoDs & $\%$ CoDs & $\%$ CoDs & $\%$ CoDs \\
\hline C. angulata & & 3.52 & 2.31 & 1.95 & 2.58 & 2.69 \\
\hline C. improvisa & 3.71 & & 3.25 & 3.41 & & 2.63 \\
\hline C. neglecta & 10.14 & 7.99 & 13.96 & 3.50 & 24.03 & 19.51 \\
\hline C. weltneri & 6.27 & & 5.54 & & 10.81 & 8.02 \\
\hline C. torosa & & 8.13 & 7.85 & 7.69 & 7.74 & \\
\hline C. pubera & 3.40 & 3.17 & & & 4.12 & 3.83 \\
\hline C. vidua & & & 2.47 & & 3.89 & 2.15 \\
\hline D. stevensoni & 4.34 & 5.14 & & 3.82 & & 1.79 \\
\hline H. incongruens & 7.81 & 6.42 & 3.60 & 4.66 & 6.00 & 7.29 \\
\hline H. salina & 2.60 & & 3.23 & 3.14 & & 2.00 \\
\hline I. bradyi & 15.33 & 14.06 & 20.83 & 22.63 & 5.35 & 18.95 \\
\hline L. inopinata & & 2.99 & 2.93 & 2.83 & & 2.13 \\
\hline P. kraepelini & 2.38 & 4.60 & 3.70 & 3.08 & 3.73 & 4.71 \\
\hline P. fallax & & & 1.51 & & 2.45 & 1.87 \\
\hline P. similis & 7.69 & 8.14 & 3.25 & 7.37 & 4.47 & 2.84 \\
\hline P. unicaudata & & & 1.78 & 1.91 & & \\
\hline P. variegata & 4.46 & 7.98 & 4.03 & 6.50 & 6.06 & \\
\hline P. zenkeri & 3.94 & 3.59 & & 2.87 & 2.37 & \\
\hline P. albicans & 2.05 & & & & & \\
\hline P. olivaceus & 13.72 & 13.24 & 10.08 & 13.65 & 6.95 & 11.11 \\
\hline T. clavata & 2.57 & 2.32 & & 1.70 & & \\
\hline
\end{tabular}

(52.25\% dissimilarity) and E2-E3 (44.33\% dissimilarity) with 97.71, 96.30 and $96.38 \%$ contributions, respectively.

The mean value of water temperature (Tw, ANOVA, $p>0.05)$, electrical conductivity (EC) and dissolved oxygen (DO, Kruskal-Wallis, p > 0.05) did not show significant differences among basins. On the other hand, average value of $\mathrm{pH}$ between Antalya and West-Mediterranean basins and elevation between Konya and Antalya, and Konya and West-Mediterranean basins were significantly (Kruskal-Wallis, $\mathrm{p}<0.05$ ) different from each other. In the sense of elevational intervals, $\mathrm{pH}$ and $\mathrm{DO}$ did not indicate meaningful unlike- 
Table 4. Influence of variables on the ordination of species on CCA diagrams in Konya, West Mediterranean and Antalya basins. Values in bold show the variables with a significant effect.

\begin{tabular}{lcccccccccc}
\hline \multirow{2}{*}{ Basins } & \multicolumn{3}{c}{ Konya } & \multicolumn{4}{c}{$\begin{array}{c}\text { West Mediterra- } \\
\text { nean }\end{array}$} & \multicolumn{4}{c}{ Antalya } \\
\cline { 2 - 11 } Variables & $\mathrm{P}$ & $\lambda$ & $\mathrm{F}$ & $\mathrm{P}$ & $\lambda$ & $\mathrm{F}$ & $\mathrm{P}$ & $\lambda$ & $\mathrm{F}$ \\
\hline Elevation & $\mathbf{0 . 0 0 2}$ & 0.73 & 3.43 & $\mathbf{0 . 0 0 8}$ & 0.52 & 2.30 & $\mathbf{0 . 0 0 2}$ & 0.96 & 4.18 \\
Electrical conductivity & $\mathbf{0 . 0 2 2}$ & 0.55 & 2.74 & $\mathbf{0 . 0 0 2}$ & 0.60 & 2.89 & 0.218 & 0.24 & 1.33 \\
pH & 0.184 & 0.26 & 1.28 & $\mathbf{0 . 0 2 8}$ & 0.41 & 2.00 & $\mathbf{0 . 0 0 6}$ & 0.49 & 2.62 \\
Water temperature & 0.116 & 0.30 & 1.56 & 0.114 & 0.31 & 1.57 & $\mathbf{0 . 0 0 6}$ & 0.68 & 3.27 \\
Dissolved oxygen & 0.574 & 0.18 & 0.89 & 0.212 & 0.26 & 1.30 & 0.840 & 0.09 & 0.44 \\
\hline
\end{tabular}

ness (Kruskal-Wallis, $\mathrm{p}>0.05)$. However, mean values of Tw and EC depicted significant dissimilarity between E1 and E2, and E2 and E3 intervals, respectively (Kruskal-Wallis, $\mathrm{p}<0.05$ ).

Total of $68,69.9$ and $70.9 \%$ of relationships between species and used environmental variables in Konya, Antalya and West-Mediterranean Basins were elucidated by the first two axes of CCA (Table S2), respectively. Of the variables, elevation is the common variable that had a significant $(p<0.05)$ effect on species composition in all basins. In addition to elevation, electrical conductivity (EC) in Konya, EC and $\mathrm{pH}$ in West-Mediterranean and $\mathrm{pH}$ and water temperature in Antalya basins are the other meaningful variables ( $\mathrm{p}<$ 0.05) on species composition (Table 4).

Most of the species ordinated on the negative sides of axes 1 and 2 in Konya basin (Fig. 2A) while almost all species except $P$. similis and $P$. olivaceus positioned on the positive sides of axes 1 and 2 in West-Mediterranean basin (Fig. 2B). In Antalya basin, all of species except H. incongruens located on the right side of axis 1 where there is only electrical conductivity arrow (Fig. 2C). The well-known cosmopolitan species, P. olivaceus and Pseudocandona albicans in Konya, and Herpetocypris reptans and I. bradyi in West-Mediterranean basin aligned relatively closer to the center of CCA diagrams (Figs. 2A and B) that means distribution of these species may not be significantly affected by the variables used. The positioning of all other species in three basins according to the effect of variables on their distributions are as in Figs. 2A, B and C. The significant correlations among environmental variables and species are given in Table 5.

Estimated tolerance $\left(t_{\mathrm{k}}\right)$ and optimum $\left(\mu_{\mathrm{k}}\right)$ levels of 19 species from whole data for five variables are given in Table 6 where H. incongruens had highest optimum (1861.55) and tolerance levels (942.23) for elevation, and the lowest optimum (14.84) was recorded for C. torosa. Candona weltneri exhibited maxi- 
mum tolerance level for water temperature (11.13) but minimum tolerance levels for electrical conductivity (17.90) and optimum for water temperature (13.33) among species. One species, F. holzkampfi showed high tolerance values for $\mathrm{pH}$ (8.96) and dissolved oxygen (10.18) (for more see Table 6).
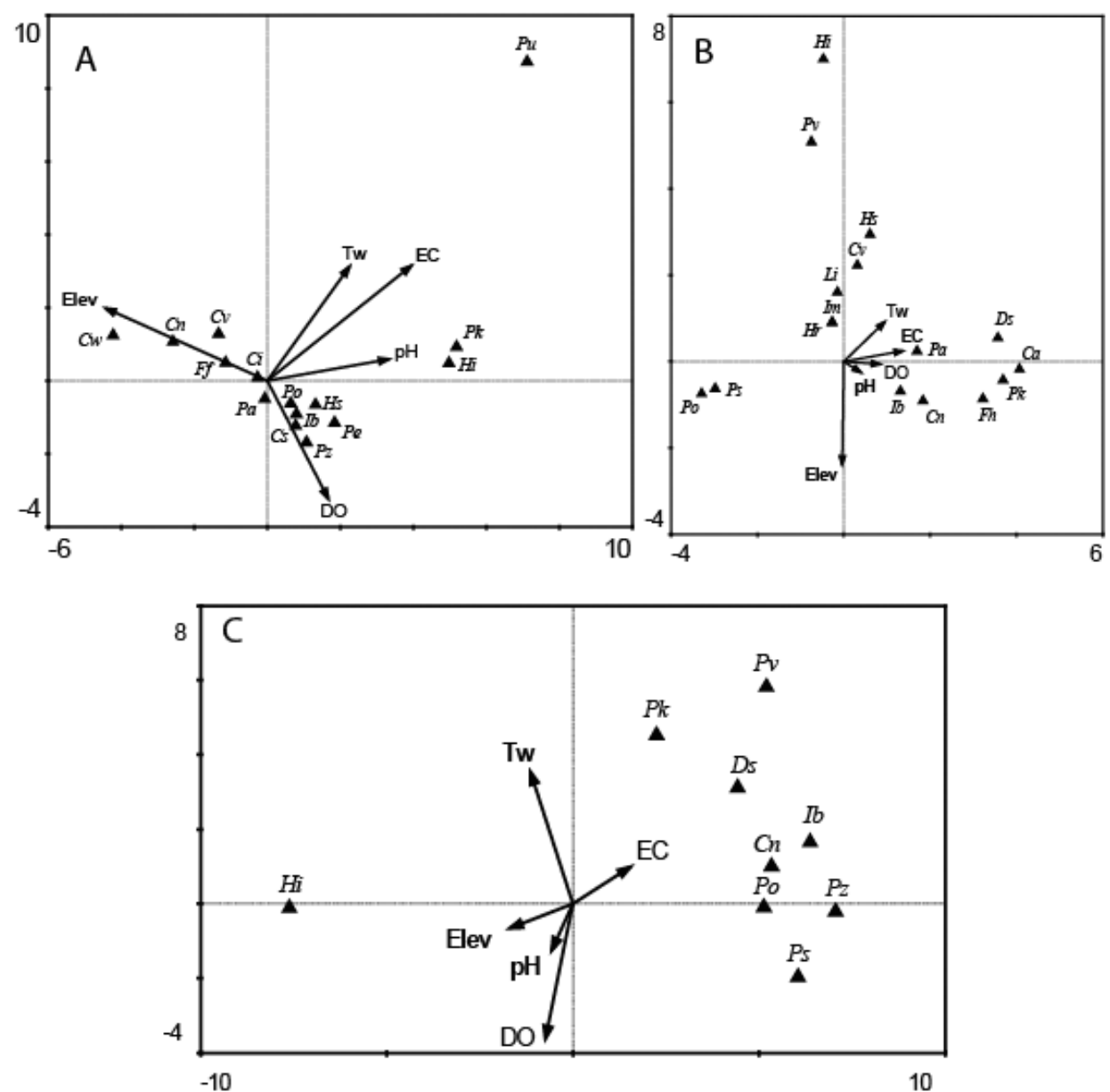

Fig. 2. Ordination of species on CCA diagrams based on the effectiveness of the variables on their distribution in Konya (A), West-Mediterranean (B) and Antalya (C) basins. Abbreviations: Elev, elevation (m a.s.l.); Tw, water temperature $\left({ }^{\circ} \mathrm{C}\right)$; $\mathrm{EC}$, electrical conductivity $(\mu \mathrm{S} / \mathrm{cm}) ; \mathrm{DO}$, dissolved oxygen (mg/l); Ca, Candona angulata; Ci, C. improvisa; Cn, C. neglecta; Cs, C. sanociensis; Cw, C. weltneri; Cv, Cypridopsis vidua; Ds, Darwinula stevensoni; Ff, Fabaeformiscandona fabaeformis; Fh, F. holzkampfi; $\mathrm{Hr}$, Herpetocypris reptans; Hi, Heterocypris incongruens; Hs, H. salina; Ib, Ilyocypris bradyi; Im, I. monstrifica; Li, Limnocythere inopinata; Pe, Paracandona euplectella; Pk, Physocypria kraepelini; Ps, Potamocypris similis; Pu, P. unicaudata; Pv, P. variegata; Pz, Prionocypris zenkeri; Pa, Pseudocandona albicans and Po, Psychrodromus olivaceus 
Table 5. Spearman Rank Correlation Analysis results among environmental variables and species.

\begin{tabular}{|c|c|c|c|c|c|c|c|}
\hline & & $\begin{array}{l}\text { Water } \\
\text { temper- } \\
\text { ature }\end{array}$ & $\begin{array}{l}\text { Con- } \\
\text { ductiv- } \\
\text { ity }\end{array}$ & Salinity & $\begin{array}{c}\text { Dis- } \\
\text { solved } \\
\text { oxygen }\end{array}$ & $\begin{array}{l}\text { Candona } \\
\text { neglecta }\end{array}$ & $\begin{array}{l}\text { Hetero- } \\
\text { cypris } \\
\text { salina }\end{array}$ \\
\hline \multirow[t]{3}{*}{ Elevation } & Corr. coeff. & $-0.251^{*}$ & $-0.551^{* *}$ & $-0.638^{* *}$ & & $0.552^{*}$ & $0.926^{* *}$ \\
\hline & Sig. (2-tailed) & 0.016 & 0.000 & 0.000 & & 0.012 & 0.008 \\
\hline & $\mathrm{N}$ & 92 & 92 & 92 & & 20 & 6 \\
\hline \multirow[t]{3}{*}{$\mathrm{pH}$} & Corr. coeff. & & & & $0.286^{* *}$ & & \\
\hline & Sig. (2-tailed) & & & & 0.006 & & \\
\hline & $\mathrm{N}$ & & & & 92 & & \\
\hline \multirow[t]{3}{*}{ Conductivity } & Corr. coeff. & & & & $-0.217^{*}$ & & \\
\hline & Sig. (2-tailed) & & & & 0.038 & & \\
\hline & $\mathrm{N}$ & & & & 92 & & \\
\hline \multirow[t]{3}{*}{ Cyprideis torosa } & Corr. coeff. & & $0.900^{*}$ & & $-0.900^{*}$ & & \\
\hline & Sig. (2-tailed) & & 0.037 & & 0.037 & & \\
\hline & $\mathrm{N}$ & & 5 & & 5 & & \\
\hline \multirow[t]{3}{*}{ Ilyocypris bradyi } & Corr. coeff. & $-0.479^{*}$ & & & & & \\
\hline & Sig. (2-tailed) & 0.018 & & & & & \\
\hline & $\mathrm{N}$ & 24 & & & & & \\
\hline
\end{tabular}

*Correlation is significant at the 0.05 level (2-tailed)

**Correlation is significant at the 0.01 level (2-tailed)

\section{DISCUSSION}

The species F. fragilis herein (Tables 1 and S1) were new for the Turkish non-marine ostracod fauna and thus, the number of non-marine ostracods in Turkey has increased to 146 species. The gamma (31) diversity of the three river basins (Konya, Antalya and West-Mediterranean) is about $21.23 \%$ of Turkey (146) when their surface area is ca 13\% of Turkey's surface area. The number of species in these basins is not very low considering their surface area. Nevertheless, the absence of basin-related studies dealing with ostracods in Turkey did not allow for any crosscheck comment about this ratio.

Binary comparisons of basins with the Shannon diversity index values for Konya and Antalya and for Antalya and West-Mediterranean basins were explained by the suggestion of "sampling effect" hypothesis (Hill et al. 1994) as the number of encountered species is expected to be high when the sampled sites increase, since the number of sampled sites in each of the Konya and West-Mediterranean basins are higher than Antalya basin. On the other hand, similar to previous studies (e.g., АкDemir \& KülкöylüoĞLu 2011, Pieri et al. 2009, Yavuzatmaca et al. 2018), comparison between the Konya and West- 


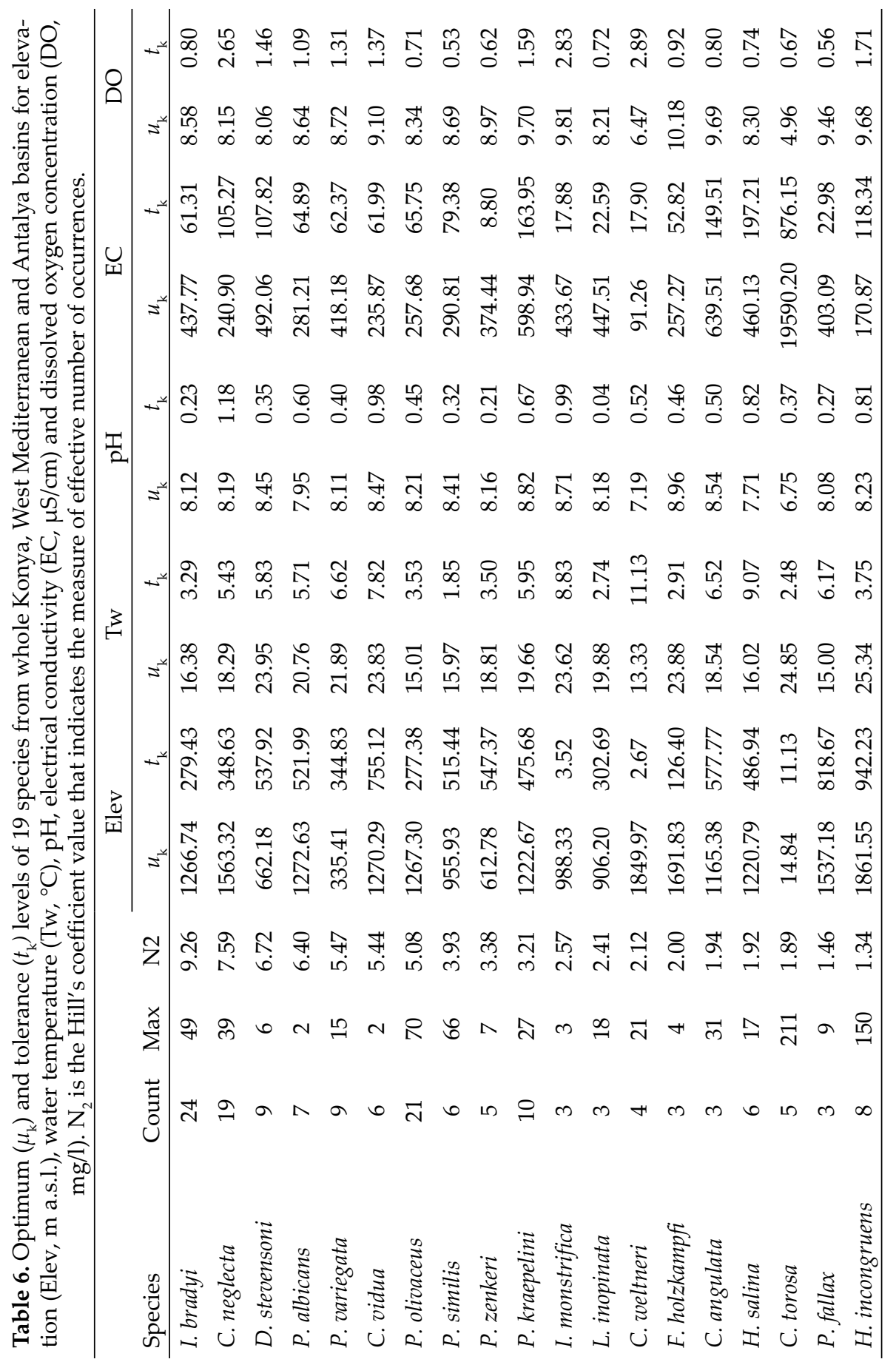


Mediterranean basins did not reinforce "sampling effect" hypothesis because their alpha index values are very close to each other. It seems that the abiotic (e.g., physico-chemical variables, habitat destruction) quality of sampled sites may affect the diversity of ostracods along with this ecological hypothesis.

The beta diversity value among three basins is larger than the dual comparisons. Of the dual comparisons, the highest beta diversity values were reported between the Konya, open Antalya, and West-Mediterranean basins, respectively (Table 2). The results of ANOSIM supports significant differences in species composition among basins and between Konya and Antalya basins $(p<0.05)$. The drivers of beta diversity are arranged as i) dispersal limitation, ii) productivity and iii) environmental heterogeneity (Astorga et al. 2014). Among them, productivity is beyond the scope of the present study. The dispersal limitation may be used as an explanation, by way of the beta diversity values for ostracods since longer distance dispersion of non-marine ostracods are achieved passively by human, wind, birds, fishes and insects (McKenzIE \& Moroni 1986, Green 2016; Valls et al. 2016). Antalya and West-Mediterranean basins have a border to Mediterranean and Aegean Sea (Fig. 1). In the summer season, touristic activities are far more intense in both basins. The presence of 13 common species in both close basins (Table 1) showed the human effect on distribution of ostracod species as previously suggested by VALLs et al. (2016). As a result, the lowest beta diversity value was noted between Antalya and West Mediterranean basins (Table 2). Indeed, the ratio of non-cosmopolitan to cosmopolitan species called as "Pseudorichness" (KüLKÖYLÜоĞLU 2013) in Antalya (0.37) and West-Mediterranean (0.40) basins indicate such anthropogenic influence when this ratio is 0.91 in Konya basin (Table 1). This is because the "Pseudorichness" ratio is smaller than one means there are possible anthropogenic effects related to disturbance (KüLKÖYLÜOĞLU 2013). Therefore, the Antalya and West-Mediterranean basins seem to be more affected than the Konya basin anthropogenically since these are under the pressure of tourist activities more than the latter one. Electrical conductivity and elevation gave rise to environmental variables heterogeneities among basins (see results) and these kinds of heterogeneities affect the beta diversity values. Of the variables, the regional factor, elevation, seems to be a deterministic factor for the highest beta diversities. Since the highest beta diversity values (Table 2) and significant average value difference of elevation (Kruskal-Wallis, $\mathrm{p}<0.05$ ) were reported between Konya and both open basins. Additionally, decreases in air and water temperatures with ascending elevation and consequently physico-chemical variables fluctuations are well documented in Yavuzatmaca et al. (2018). The significant negative correlations of elevation with water temperature $(p<0.05)$ and electrical conductivity $(\mathrm{p}<0.01)$ here (Table 5$)$ support this previous statement. This shows that 
elevation indirectly influences the occurrences of ostracod species. Therefore, species with wider tolerance ranges (cosmopolitans) have advantages over non-cosmopolitans in aquatic bodies. This is the case in the present study. Since cosmopolitan species (e.g., I. bradyi, P. olivaceus, C. neglecta), appear to play important roles with high percentages in the dissimilarities and alpha diversities among basins (see Table 3).

Most recently, KüLKÖYLÜOĞLU et al. (2017c) implied the importance of geographical differences (or regional factor) for beta diversity in the Düzce and Karabük provinces, Turkey. On the other hand, Higuti et al. (2009) proposed that beta diversity is equally affected by both local and regional factors, indicating the presence of low beta diversity between homogeneous systems. The significant differences of elevation and high beta diversity between closed and open basins herein reinforce the final statement of Higuti et al. (2009). In Belarus, the significant correlation of alpha diversity of ostracods with temperature was recorded by Nagorskaya \& Keyser (2005) when Higuti et al. (2009) suggested that local factors had more influence than regional factor on alpha diversity in Brazil. Other studies in Turkey have suggested that the suitability of habitats (ecological conditions) would be better than altitude, $\mathrm{pH}$, and salinity as explanatory factors for ostracod diversity (KüLKÖYLÜOĞLU et al. 2012c). Overall, the results of the studies mentioned above and the present study suggest that beta diversity is affected most by regional factors (e.g., elevation, system (open and/or closed basins)) and then by local factors (e.g., electrical conductivity, water temperature, $\mathrm{pH}$ ) while alpha diversity is mainly under the control of local factors (see below).

CCA explored elevation as a common factor on the alpha diversity in all basins (Table 4). According to the results of 30 studies done in and out of Turkey, elevation was found to be an important variable on alpha diversity only in five studies (Table S3). Whereas the other effective local variables herein (electrical conductivity, $\mathrm{pH}$ and water temperature) (Table 4) were commonly indicated as influential variables on ostracod species composition, e.g., electrical conductivity in 16, water temperature in 14 and $\mathrm{pH}$ in 10 studies (Table S3). Consequently, this literature survey and the results of the present study may pinpoint that local factors have a greater impact than regional factors on alpha diversity of ostracods. The relationships of local and regional factors with individual species show difference among the regions (Figs. 2A, B and C). For example, $C$. neglecta had a significant correlation with elevation but oriented on the opposing side of this variable in West-Mediterranean (Fig. 2C) and did not locate close the arrow of variable in Antalya (Fig. 2B) while it showed a close relationship with elevation in Konya (Fig. 2A). Also, C. neglecta had high optimum and tolerance levels $(1563.32 \pm 348.63)$ (Table 6$)$ and a wide range (0-3194 $\mathrm{m}$ a.s.1.) (YavuZatmacA et al. 2017a) of elevation. This is the case 
for other common species I. bradyi which had a strong correlation with water temperature but did not show any close relationship in all basins (Figure 2A, $\mathrm{B}$ and $\mathrm{C})$ when there is a wide range of water temperature $\left(1.68-35.5^{\circ} \mathrm{C}\right)\left(\mathrm{Y}_{\mathrm{A}}-\right.$ vUZATMACA et al. 2017a, the present study) for species (see Table 6 and Figs. $2 \mathrm{~A}, \mathrm{~B}$ and $\mathrm{C}$ ). This shows that even if a species has a low or high optimum and tolerance levels for a variable, the relationship of species with the same variable may vary in different regions. Also, species are affected in different ways by each variable because ecological variables (e.g., $\mathrm{pH}$, dissolved oxygen, water temperature) show correlations among themselves (Table 5). Since we cannot determine which variable is primarily important for the distribution and occurrence of an individual species, it is inevitable to encounter the distinct relationships of a species with the same variable in different regions. Although this is the case, optimum and tolerance levels of species and their relationship with ecological variables provide important information for paleontologists to make retrospective environment estimates and to determine the changes that have occurred.

As previously stated (e.g., KüLKÖYLÜOĞLU et al. 2012c, YAvUZATMACA et al. $2017 a, b)$, the high species diversity was reported in the mid-elevational interval in the present study (Table 2). Whereas the finding of high diversity at low (e.g., Pèrez et al. 2015, Yavuzatmaca et al. 2018) and high (e.g., KüLKöYlüoĞLU et al. 2012a, 2016) elevational intervals are also available in the literature. The difference between the present study and previous ones is the difference in the elevation ranges used. We investigated $800 \mathrm{~m}$, while most other studies used ranges about 100, 150, 200 or $250 \mathrm{~m}$. Thereby, this wide range allows us to see the effect of elevation on the species in a wide perspective. It is known that some of the species are of narrow tolerance ranges while others have very wide ranges (Table 5). When we look at the differences in species composition among the elevational intervals subjected herein (Table 3), especially the species with cosmopolitan distribution (e.g., I. bradyi, C. neglecta, P. olivaceus) tend to contribute with high percentages. The average value differences of water temperature and electrical conductivity among elevational intervals herein (see results) strengthened the changing of ecological variables with elevation as proposed previously (KüLKÖYLüOĞLU et al. 2012c, McCAIN \& GrYTNEs 2010; SCHINDLER et al. 1990). This kind of change explains the conditions in mid and high elevations. Since if the species have wide ecological tolerance ranges especially cosmopolitans - they may occur in all (e.g., C. neglecta, C. angulata, H. incongruens, I. bradyi) when others occur in limited elevational ranges (e.g., T. clavata, C. improvisa, C. pubera). Of course, this does not mean all cosmopolitans are found everywhere because their tolerance levels vary among themselves. On the other hand, conditions in low ranges may be assumed to be suitable for many species but biotic factors (e.g., competition, prey/predation relationship, anthropogenic environmental deterioration) can become critical. 
"Pseudorichness $(\mathrm{PR})$ " ratio of E1 $(\mathrm{PR}=0.27)$ may demonstrate the effect of human on aquatic bodies when compared with mid $(E 2, P R=0.67)$ and high $(\mathrm{E} 3, \mathrm{PR}=0.78)$ elevational intervals that is also supported by the numbers of cosmopolitan species (15 spp.) found in low elevation. All of them indicate that at low elevations biotic factors are more effective than abiotic factors when compared with high elevations. Therefore, further studies including biotic factors are needed to make better inferences about the effect of elevation on ostracods.

Cyprideis torosa is an opportunistic species that occur mostly in brackish to saline water bodies (e.g., ponds, lakes, lagoons, estuaries) (Меısch 2000). SANDBERG (1964) suggested nodes (lateral projections on valves) are observed on the valves of species in conditions with $<5 \%$ salinity. The occurrence of these nodes helps the animal to increase osmotic pressure during molting in low saline environments (KeYser 2005). Indeed, a total of 327 individual species without nodes were collected from four samplings in three lakes while one individual with nodes was encountered from a creek. The average values of electrical conductivity $(14837.5 \mu \mathrm{S} / \mathrm{cm})$ and salinity $(7.28 \%$ o of the lakes are higher than the values of electrical conductivity $(573 \mu \mathrm{S} / \mathrm{cm})$ and salinity $(0.28 \%$ o) of the creek (see Table S1). Also, the species with the highest optimum and tolerance values (Table 6) displayed a strong correlation with electrical conductivity (Table 5). Thus, the findings of the present study support previous statements that presence of $C$. torosa with or without nodes is indeed dependent on changes in water salinity.

Finally, the present study provides important contributions to the freshwater ostracod fauna of Turkey and ecological information about ostracod species. Although cosmopolitans are positive indicators, they play an important role in the diversities (alpha, beta and gamma) of basins and elevational intervals. Local and regional factors are best suited to elucidate the alpha and beta diversities of ostracods, respectively among basins. Human-induced deterioration is less in the Konya basin than in open basins (Antalya and WestMediterranean) but this does not mean to ignore touristic activities (referring to anthropogenic activities) that have economic and ecological significance, (e.g., habitat deterioration in the present study). The occurrence of species at low elevations may be under the control of biotic and human-mediated abiotic factors while abiotic factors may be effective at high elevations. This study has also shown the lack of basin-related studies in Turkey. Therefore, increasing in the number of basin-related studies in the future will be of great importance to the evaluation of aquatic environments and in determining the regional species pool. 
Acknowledgements - I wish to thank researcher Mr. Daniel Reinald (North Carolina State University, USA) for his help with English. I would like to give my sincere appreciation to Prof. Dr. Okan Külköylüoğlu (Bolu Abant İzzet Baysal University, Turkey) and an anonymous reviewer for their constructive comments on the first draft. Mrs. Filiz Batmaz and Mr. Çağatay Çapraz were thanked for their help during field and laboratory studies.

\section{REFERENCES}

Aкdemir, D. (2008): Differences of Ostracoda (Crustacea) Assemblages among two maar lakes and one sinkhole lake in the Konya region (Turkey). - Turkish Journal of Zoology 32(2): 107-113.

АкреміR, D. \& KüLкӧylüоĞLu, O. (2011): Freshwater Ostracoda (Crustacea) of Diyarbakır Province, including a new report for Turkey. - Turkish Journal of Zoology 35: 671-675. https://doi.org/10.3906/zoo-0912-32

АкдеміR, D. \& KülкöylüоĞLu, O. (2014): Preliminary study on distribution, diversity and ecological characteristics of nonmarine Ostracoda (Crustacea) from Erzincan region (Turkey). - Turkish Journal of Zoology 38: 421-431. https://doi.org/10.3906/zoo-1301-16

Aкdemir, D., KülкöylüoĞLu, O., Yavuzatmaca, M. \& SARI, N. (2016): Freshwater ostracods (Crustacea) of Gaziantep (Turkey) and their habitat preferences according to movement ability. - Fundamental and Applied Limnology 187(4): 307-314. https://doi. org/10.1127/fal/2016/0665.

Altinsaçli, S. (2004): Investigation on Ostracoda (Crustacea) fauna of some important wetlands of Turkey. - Pakistan Journal of Biological Sciences 7(12): 2130-2134. https:// doi.org/10.3923/pjbs.2004.2130.2134

Altinsaçli, S. \& Mezquita, F. (2008): Ostracod fauna of salt Lake Acıgöl (Acı Tuz) (Turkey). - Journal of Natural History 42: 1013-1025. https://doi.org/10.1080/00222930701851735

Astorga, A., Death, R., Death, F., Paavola, R., Chakraborty, M. \& Muotka, T. (2014): Habitat heterogeneity drives the geographical distribution of beta diversity: the case of New Zealand stream invertebrates. - Ecology and Evolution 4(13): 2693-2702. https://doi.org/10.1002/ece3.1124

Brown, R., Jacobs, L. A. \& PeEt, R. K. (2007): Species richness: small scale. - Encyclopedia of Life Sciences, John Wiley \& Sons, Ltd., pp. 1-8. https://doi.org/10.1002/9780470015902. a0020488

Delorme, L. D. (1991): Ostracoda. Pp. 811-848. - In: Thorp, J. H. \& Covich, A. P. (eds): Ecology and Classification of North American Freshwater Invertebrates, 2nd ed. Academic Press. https://doi.org/10.1016/B978-012690647-9/50021-1

DüGel, M., KüLKöYlüOĞLU, O. \& KILIÇ, M. (2008): Species assemblages and habitat preferences of Ostracoda (Crustacea) in Lake Abant (Bolu, Turkey). - The Belgian Journal of Zoology 138(1): 50-59.

Engen, S., Saether, B., Sverdrup-Thygeson, A., Grotan, V. \& Odegaard, F. (2008): Assessment of species diversity from species abundance distributions at different localities. - Oikos 117(5): 738-748. https://doi.org/10.1111/j.0030-1299.2008.16466.x

European Commission, (2018): Available at http://ec.europa.eu/environment/index_en.htm [Accessed 2 August 2018]

Escrivì, A., Poquet, J. M. \& Mesquita-Joanes, F. (2015): Effects of environmental and spatial variables on lotic ostracod metacommunity structure in the Iberian Peninsula. - Inland Waters 5: 283-294. https://doi.org/10.5268/IW-5.3.771 
Escrivà, A., Rueda, J., Armengol, X. \& Mesquita-Joanes, F. (2014): Artificial dam lakes as suitable habitats for exotic invertebrates: Ostracoda ecology and distribution in reservoirs of the Eastern Iberian Peninsula. - Knowledge and Management of Aquatic Ecosystems 412: 09. https://doi.org/10.1051/kmae/2013091

Gibb, H., Johansson, T., Stenbacka, F. \& HJÄLtÉN, J. (2013): Functional Roles Affect Diversity-Succession Relationships for Boreal Beetles. - PLOS ONE 8(8): 1-14. https://doi. org/10.1371/journal.pone.0072764

GreEn, A. J. (2016): The importance of waterbirds as an ovelooked pathway of invasion for alien species. - Diversity \& Distributions 22: 239-247. https://doi.org/10.1111/ddi.12392

Guo, Y., Frenzel, P., Börner, N., Akita, L. G. \& Zhu, L. (2013): Recent Ostracoda of Taro Co (Western Tibetan Plateau). IL Naturalista Siciliano 37(1): 161-162. - In: Abstract of $17^{\text {th }}$ International Symposium on Ostracoda, Roma, Italy, 23-26 July 2013.

Gülen, D. (1985): The species and distribution of the group of Podocopa (OstracodaCrustacea) in freshwaters of Western Anatolia. - İstanbul Üniversitesi Fen Fakültesi Mecmuası Seri B 50: 65-80.

Gülen, D. \& Altinsaçli, S. (1999): The Ostracoda (Crustacea) fauna of Sakarya river basin. - Geosound 35: 69-84.

Higuti, J., Lansac-Tôha, F. A., Velho, L. F. M. \& Martens, K. (2009): Biodiversity of non-marine ostracods (Crustacea, Ostracoda) in the alluvial valley of the upper Paraná river. - Brazilian Journal of Biology 69: 661-668. https://doi.org/10.1590/S151969842009000300020

Hill, J., Curran, P. J. \& Foody, G. M. (1994): The Effect of Sampling on the SpeciesArea Curve. - Global Ecology and Biogeography Letters 4(4): 97-106. https://doi. org $/ 10.2307 / 2997435$

Hill, M. O. (1973): Diversity and evenness: A unifying notation and its consequences. Ecology 54(2): 472-432. https://dx.doi.org /10.2307/1934352.

IglikowsKA, A. \& NАміотко, T. (2012): The impact of environmental factors on diversity of Ostracoda in freshwater habitats of subarctic and temperate Europe. - Annales Zoologici Fennici 49: 193-218. https://doi.org/10.5735/086.049.0401

Juggins, S. (2003): Software for Ecological and Palaeoecological Data Analysis and Visualization, - C2 User Guide. University of Newcastle, Newcastle-upon-Tyne, UK.

Keyser, D. (2005): Histological peculiarities of the noding process in Cyprideis torosa (Jones) (Crustacea, Ostracoda). - Hydrobiologia 538: 95-106. https://doi.org/10.1007/s10750004-4940-x

KüLKÖYLÜOĞLU, O. (2003): Ecology of freshwater Ostracoda (Crustacea) from lakes and reservoirs in Bolu, Turkey. - Journal of Freshwater Ecology 18(3): 343-347. https://doi.org/ 10.1080/02705060.2003.9663968

KüLKÖyLüoĞLU, O. (2004): On the usage of ostracods (Crustacea) as bioindicator species in different aquatic habitats in the Bolu region, Turkey. - Ecological Indicators 4: 139-147. https://doi.org/10.1016/j.ecolind.2004.01.004

KüLKÖYLÜOĞLU, O. (2005a): Ecology and phenology of freshwater ostracods in Lake Gölköy (Bolu, Turkey). - Aquatic Ecology 39: 295-304. https://doi.org/10.1007/s10452-0050782-5

KüLKÖYLÜOĞLU, O. (2005b): Ecological requirements of freshwater Ostracoda (Crustacea) in two limnocrene springs (Bolu, Turkey). - Annales de Limnologie - International Jurnal of Limnology 41(4): 237-246. https://doi.org/10.1051/limn/2005016

KüLKöYLÜоĞLU, O. (2013): Diversity, distribution and ecology of non-marine Ostracoda (Crustacea) in Turkey: application of pseudorichness and cosmoecious species concepts. - Recent Research Development in Ecology 4: 1-18. 
KülköylüoĞLu, O., Akdemir, D., SARi, N., Yavuzatmaca, M., Oral, C. \& BaşaK, E. (2013): Distribution and ecology of Ostracoda (Crustacea) from troughs in Turkey. - Turkish Journal of Zoology 37: 277-287. https://doi.org/10.3906/zoo-1205-17

KülкöylüoĞlu, O., Акdemir, D., Yavuzatmaca, M. \& Yilmaz, O. (2015): A checklist of recent non- marine Ostracoda (Crustacea) of Turkey with three new records. - Review of Hydrobiology 8(2): 77-90.

KüLKÖYLÜOĞLU, O., DüGEL, M. \& Kiliç M. (2007): Ecological requirements of Ostracoda (Crustacea) in a heavily polluted shallow lake, Lake Yeniçağa (Bolu, Turkey). - Hydrobiologia 585: 119-133. https://doi.org/10.1007/s10750-007-0633-6

KüLKÖYLÜOĞLU, O., SARI, N. \& AKDEMiR, D. (2012a): Distribution and ecological requirements of ostracods (Crustacea) at high altitudinal ranges in Northeastern Van (Turkey). - Annales de Limnologie-International Journal of Limnology 48: 39-51. https://doi. org/10.1051/limn/2011060

KülköylüoĞlu, O., Sari, N., Akdemir, D., Yavuzatmaca, M. \& Altinbă̆, C. (2012b): Distribution of sexual and asexual Ostracoda (Crustacea) from different altitudinal ranges in the Ordu region of Turkey: Testing the Rapoport Rule. - High Altitude Medicine $\mathcal{E}$ Biology 13(2):126-136. https://doi.org/10.1089/ham.2011.1111.

KülköylüoĞLU, O., TANYeRI, M. \& Yilmaz, O. (2017a): Alpha and beta species diversity of freshwater Ostracoda (Crustacea) and their seasonal distribution in Seben-Taşliyayla reservoir (Bolu, Turkey). - Turkish Journal of Fisheries and Aquatic Sciences 17: 13571365. https://doi.org/10.4194/1303-2712-v17_6_28

KülköylüoĞLU, O., Yavuzatmaca, M., Акdemir, D. \& Sari, N. (2012c): Distribution and Local Species Diversity of Freshwater Ostracoda in Relation to Habitat in the Kahramanmaraş Province of Turkey. - International Review of Hydrobiology 97(4): 247261. https://doi.org/10.1002/iroh.201111490

KülköylüoĞLu, O., Yavuzatmaca, M., Çelen, E., Akdemir, D. \& Dalkiran, N. (2018): Ecological classification of the freshwater Ostracoda (Crustacea) based on physicochemical properties of waters and habitat preferences. - Annales de Limnologie - International Journal of Limnology 54: 26. https://doi.org/10.1051/limn/2018017

KülкöylüoĞLu, O., Yavuzatmaca, M., SARI, N. \& Aкdemir, D. (2016): Elevational distribution and species diversity of freshwater Ostracoda (Crustacea) in Çankırı region (Turkey). - Journal of Freshwater Ecology 31(2): 219-230. https://doi.org/10.1080/02705 060.2015.1050467

KülköylüoĞlu, O., Yavuzatmaca, M., Tanyeri, M. \& Yilmaz, O. (2017b): Ostracoda (Crustacea) species composition and environmental correlates in diffeerent aquatic habitats of the Zonguldak and Bartın regions (Turkey). - Turkish Journal of Zoology 41: 686-695. https://doi.org/10.3906/zoo-1512-36

KülköYlüoĞLU, O., Yilmaz, S. \& Yavuzatmaca, M. (2017c): Comparison of Ostracoda (Crustacea) species diversity, distribution and ecological characteristics among habitat types. - Fundamental and Applied Limnology 190(1): 63-86. https://doi.org/ 10.1127/ $\mathrm{fal} / 2017 / 0872$

Laprida, C., Diaz, A. \& RAtTo, N. (2006): Ostracods (Crustacea) from thermal waters, southern Altiplano, Argentina. - Micropaleontology 52: 177-188. https://doi.org/10.2113/ gsmicropal.52.2.177

Martínez-García, B., Pascual, A., Rodríguez-Lázaro, J., Martín-Rubio, M., \& Rofes, J. (2013): The Ostracoda (Crustacea) of the Tina Menor estuary (Cantabria, southern Bay of Biscay): Distribution and ecology. - Journal of Sea Research 83: 111-122. https:// doi.org/10.1016/j.seares.2013.03.014 
Martinez-Garcia, B., Suarez-Hernando, O., Mendicoa, J. \& Murelaga, X. (2015): Living ostracod species from permanent and semi-permanent ponds of Bardenas Reales de Navarra (Northern Spain) with remarks on their ecological requirements. - Ameghiniana 52: 598-612. https://doi.org/10.5710/AMGH.17.07.2015.2895

McCain, C. M. \& Grytnes, J. A. (2010): Elevational gradients in species richness. - In: Encyclopedia of Life Sciences. John Wiley \& Sons Ltd., Chichester. https://doi. org/10.1002/9780470015902.a0022548

McKenzie, K. G. \& Moroni, A. (1986): Man as an agent of crustacean passive dispersal via useful plants: exemplified by Ostracoda ospiti esteri of the Italian Ricefields ecosystem: and implications arising therefrom. - Journal of Crustacean Biology 6(2): 181-198. https://doi.org/10.1163/193724086X00019

Мeisch, C. (2000): Freshwater Ostracoda of Western and Central Europe. Süßwasserfauna von Mitteleuropa, 8. - Spektrum Akademischer Verlag, Heidelberg I-xii.

Mezquita, F., Griffiths, H. I., Sanz, S. J., Soria, M. \& Pinon, A. (1999): Ecology and Distribution of Ostracods Associated with Flowing Waters in the Eastern Iberian Peninsula. - Journal of Crustacean Biology 19: 344-354. https://doi.org/10.1163/193724099X00150

Mischke, S., Almogi-Labin, A., Ortal, R., Rosenfeld, A., Schwab, M. J. \& Boomer, I. (2010): Quantitative reconstruction of lake conductivity in the Quaternary of the Near East (Israel) using ostracods. - Journal of Paleolimnology 43: 667-688. https://doi. org/10.1007/s10933-009-9359-y

NAgorsKAYA, L. \& KEYSER, D. (2005): Habitat diversity and ostracod distribution patterns in Belarus. - Hydrobiologia 538: 167-178. https://doi.org/10.1007/s10750-004-4959-z

ÖzuluĞ, O. (2011): A preliminary study on Ostracoda (Crustacea) fauna of the Istranca Streams-Turkey. - Journal of Fisheries Sciences 5(2): 93-98. https://doi.org/10.3153/jfscom.2011011

Pärtel, M., Zobel, M., Zobel, K. \& Van Der Maarel, E. (1996): The species pool and its relation to species richness: evidence from Estonian plant communities. - Oikos 75: 111-117. https://doi.org/10.2307/3546327

Pèrez, L., Lozano-Garcia, S. \& Caballero, M. (2015): Non-marine ostracodes from highland lakes in East-central Mexico. - Revista de Biologica Tropical (International Journal of Tropical Biology and Conservation) 63(2): 401-425. https://oi.org/10.15517/rbt. v63i2.15240

Pieri, V., Martens, K., Sтосh, F. \& Rossetti, G. (2009): Distribution and ecology of non-marine ostracods (Crustacea, Ostracoda) from Friuli Venezia Giulia (NE Italy). - Journal of Limnology 68(1): 1-15. https://doi.org/10.4081/jlimnol.2009.1

Rasouli, H., Aygen, C. \& KüLKöylüoĞLU, O. (2014): Contribution to the freshwater Ostracoda (Crustacea) fauna of Turkey: Distribution and ecological notes. - Turkish Journal of Fisheries and Aquatic Sciences 20: 11-20. https://doi.org/10.4194/1303-2712-v14_1_02

Ricciardi, A. \& Rasmussen, J. B. (1999): Extinction rates of North American freshwater fauna. - Conservation Biology 13(5): 1220-1222. https://doi.org/10.1046/j.15231739.1999.98380.x

Rodriguez-Lazaro, J. \& Ruiz-Muñoz, F. (2012): A general introduction to ostracods: morphology, distribution, fossil record and applications. - In: Horne, D. J., Holmes, J. A., Rodriguez-Lazaro, J. \& Viehberg, F. A. (eds): Development in Quaternary Science, Ostracoda as proxies for Quaternary climate change. Elsevier, Amsterdam, 1-14.

SANDBERG, P. (1964): The ostracod genus Cyprideis in the Americas. - Stockholm Contributions in Geology 12: 1-178. 
Schindler, D. W., Beaty, K. G., Fee, E. J., Cruikshank, D. R., Debruyn, E. R., Findlay, D. L., Linsey, G. L. \& SHEARER, J. A. (1990): Effects of climatic warming on lakes of the central boreal forest. - Science 250: 967-970. https://doi.org/10.1126/science.250.4983.967

Seaby, R. M. \& Henderson, P. A. (2006): Species diversity and richness version 4. - Pisces Conservation Ltd., Lymington, England.

SøndergaARd, M. \& Jeppesen, E. (2007): Anthropogenic impacts on lake and stream ecosystems, and approaches to restoration. - Journal of Applied Ecology 44: 1089-1094. https:// doi.org/10.1111/j.1365-2664.2007.01426.x

Strayer, D. L. \& Dudgeon, D. (2010): Freshwater biodiversity conservation: recent progress and future challenges. - Journal of the North American Benthological Society 29(1): 344-358. https://doi.org/10.1899/08-171.1

Ter BraAk, C. J. F. (1986): Canonical correspondence analysis: A new eigenvector technique for multivariate direct gradient analysis. - Ecology 67: 1167-1179. https://doi. org/10.2307/1938672

Trmeu (2017): Wastewater treatment action plan, 2017-2023. - Turkey Republic Ministry of Environment and Urban, Ankara, 302 pp.

Trmfwm (2016): Action plans for lakes and wetlands (2016-2018). Turkey Republic Ministry of Forest and Water Management, Ankara, $191 \mathrm{pp}$. [in Turkish]

Torres Saldarriaga, A. \& Martínez, J. I. (2010): Ecology of non-marine ostracoda from La Fe reservoir (El Retiro, Antioquia) and their potential application in paleoenvironmental studies. - Revista de la Academia Colombiana de Ciencias Exactas, Fisicas y Naturales 34(132): 397-409.

UÇAK, S., KüLKÖYLÜOĞLU, O., АкDEmir, D. \& BAşAK, E. (2014): Distribution, diversity and ecological characteristics of freshwater Ostracoda (Crustacea) in shallow aquatic bodies of the Ankara region, Turkey. - Wetlands 34: 309-324. https://doi.org/10.1007/ s13157-013-0499-5

Valls, L., Castillo-Escrivá, A., Mesquita-Joanes, F. \& Armengol, X. (2016): Humanmediated dispersal of aquatic invertebrates with waterproof footwear. - Ambio 45: 99-109. https://doi.org/10.1007/s13280-015-0689-x

Valls, L., Rueda, J. \& Mesquita-Joanes, F. (2014): Rice fields as facilitators of freshwater invasions in protected wetlands: the case of Ostracoda (Crustacea) in the Albufera Natural Park (E Spain). - Zoological Studies 53: 68. https://doi.org/10.1186/s40555-0140068-5

Van der Meeren, T., Almendinger, J. E., Ito, E. \& Martens, K. (2010): The ecology of ostracodes (Ostracoda, Crustacea) in western Mongolia. - Hydrobiologia 641: 253-273. https://doi.org/10.1007/s10750-010-0089-y

VIEHBERG, F. (2006): Freshwater ostracod assemblages and their relationship to environmental variables in waters from northeast Germany. - Hydrobiologia 571: 213-224. https://doi.org/10.1007/s10750-006-0241-x

Whittaker, R. H. (1972): Evolution and measurement of species diversity. - Taxon 21: 213251. https://doi.org/10.2307/1218190

Williams, M., Siveter, D. J., Salas, M. J., Vannier, J., Popov, L. E. \& Pour, M. G. (2008): The earliest ostracods: The geological evidence. - Senckenbergiana Lethaea 88(1): 11-21. https://doi.org/10.1007/BF03043974

Wilson, M. V. \& Shmida, A. (1984): Measuring beta diversity with presence/absence data. - Journal of Ecology 72: 1055-1064. https://doi.org/10.2307/2259551

Yavuzatmaca, M., KülköylüoĞlu, O., Akdemir, D. \& Çelen, E. (2018): On the relationship between the occurrence of ostracod species and elevation in Sakarya province, 
Turkey. - Acta Zoologica Academiae Scientiarum Hungaricae 64(4): 329-354. https://doi. org/10.17109/AZH.64.4.329.2018

Yavuzatmaca, M., KülкöylüoĞLu, O. \& Yilmaz, O. (2015): Distributional patterns of non-marine Ostracoda (Crustacea) in Adiyaman province (Turkey). - Annales de Limnologie-International Journal of Limnology 51(2): 101-113. https://doi.org/10.1051/ $\operatorname{limn} / 2015005$

YavuzatmacA, M., KüLкÖYlüOĞLu, O. \& Yilmaz, O. (2017a): Estimating distributional patterns of non-marine Ostracoda (Crustacea) and habitat suitability in the Burdur province (Turkey). - Limnologica 62: 19-33. https://doi.org/10.1016/j.limno.2016.09.006

Yavuzatmaca, M., KülköylüoĞlu, O., Y Ilmaz, O. \& Aкdemir, D. (2017b): On the relationship of ostracod species (Crustacea) to shallow water ion and sediment phosphate concentration across different elevational range (Sinop, Turkey). - Turkish Journal of Fisheries and Aquatic Sciences 17: 1333-1346. https://doi.org/10.4194/1303-2712-v17_6_40

Zobel, M., Van Der MaArel, E. \& Dupre, C. (1998): Species pool: the concept, its determination and significance for community restoration. - Applied Vegetation Science 1: 55-66. https://doi.org/10.2307/1479085

Received December 17, 2018, accepted May 22, 2019, published August 12, 2019 


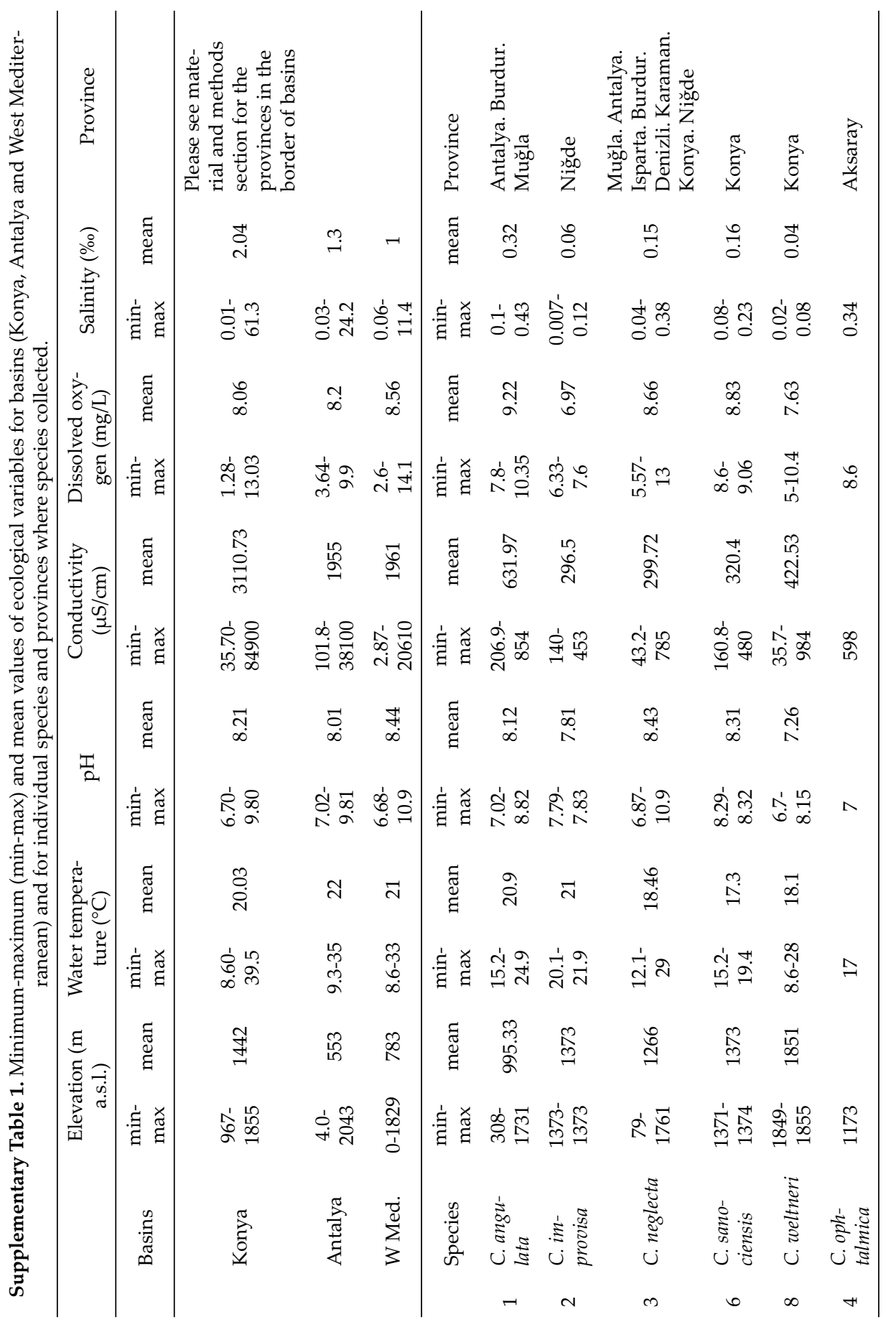

Acta Zool. Acad. Sci. Hung. 65, 2019 


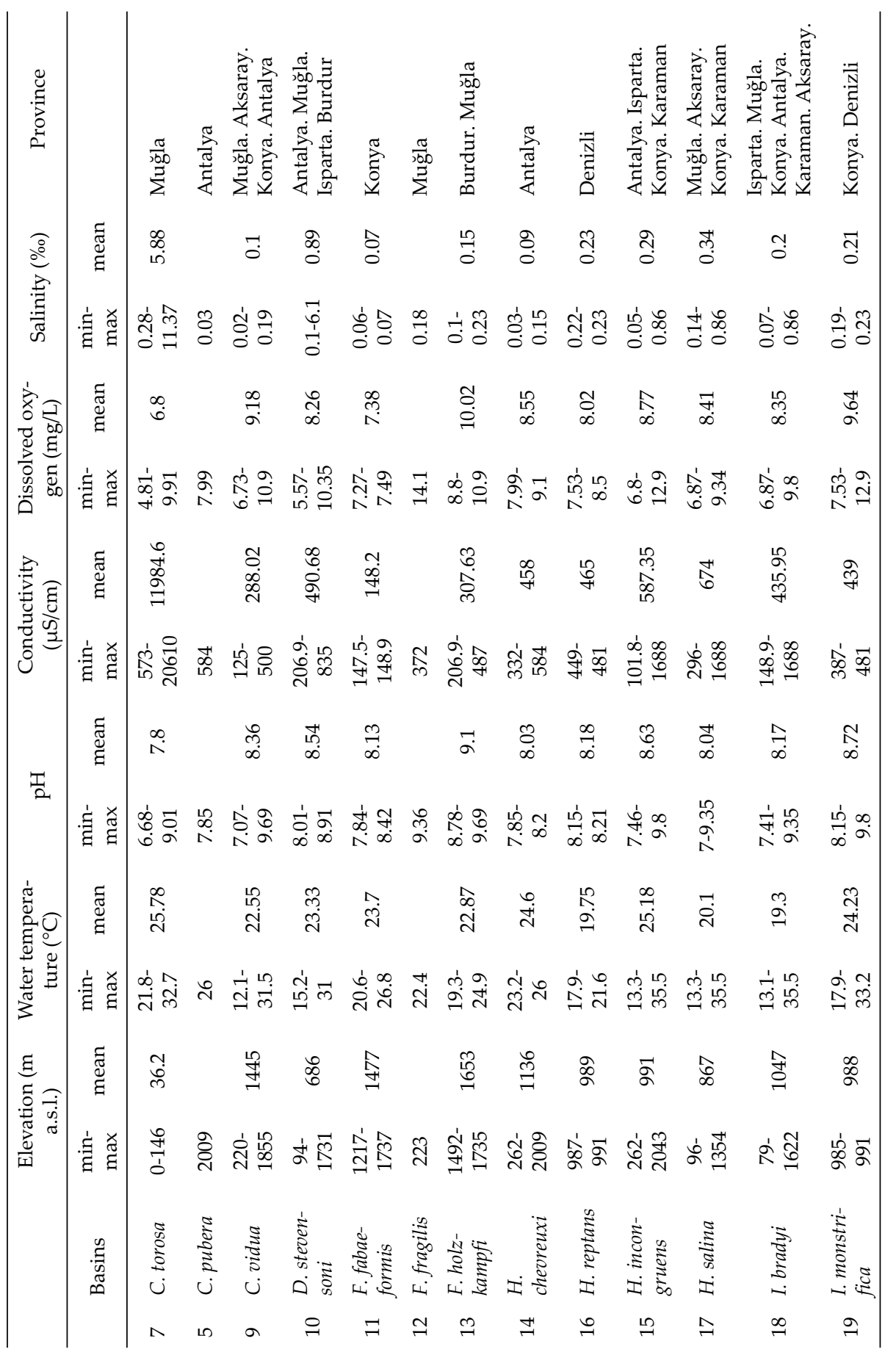




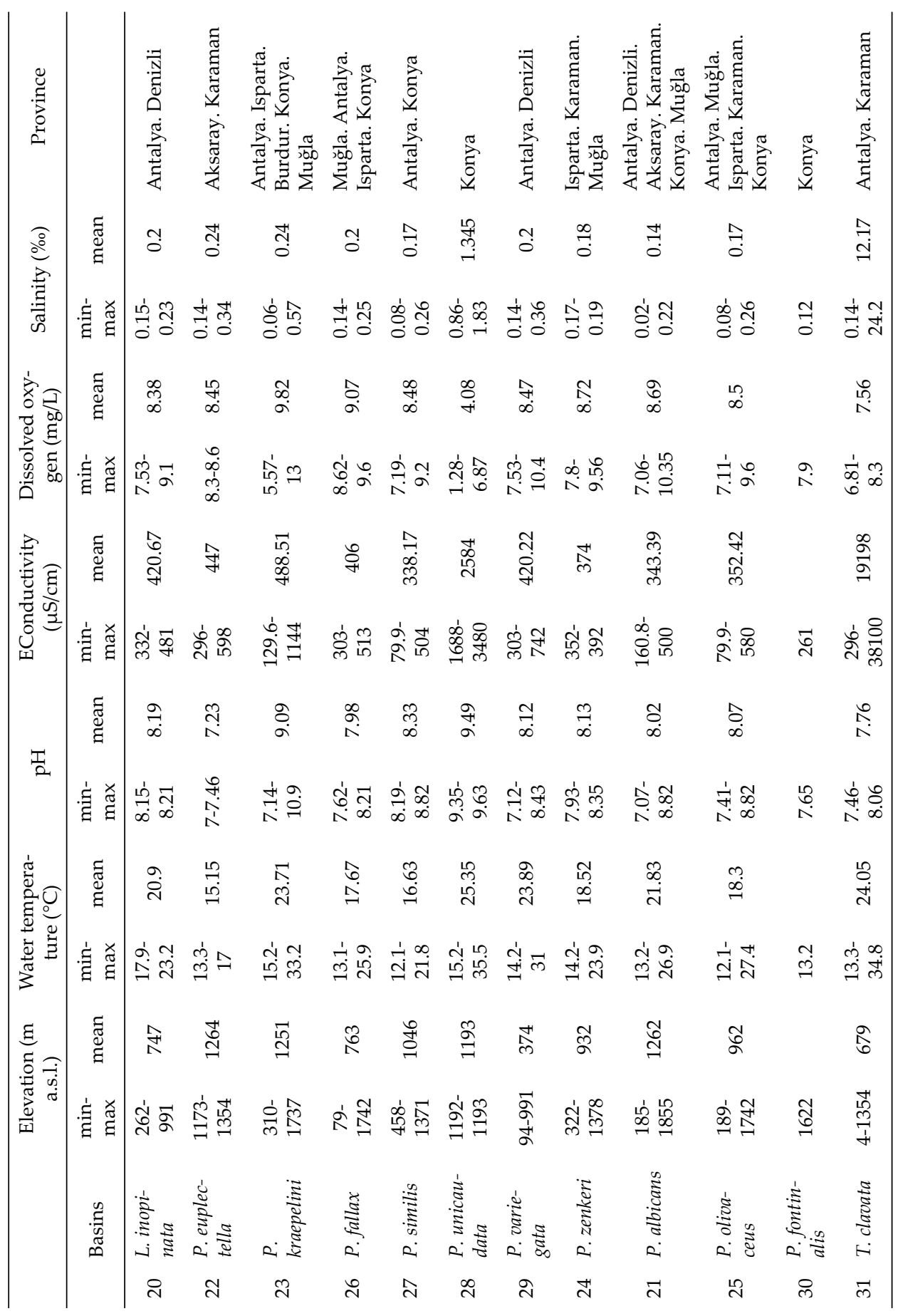

Acta Zool. Acad. Sci. Hung. 65, 2019 
Supplementary Table 2. Summary tables of CCA for Konya, Antalya and West Mediterranean basins.

\begin{tabular}{lccccc}
\hline & \multicolumn{5}{c}{ Konya Basin } \\
\cline { 2 - 6 } Axes & 1 & 2 & 3 & 4 & Total inertia \\
\hline Eigenvalues & 0.81 & 0.57 & 0.34 & 0.24 & 7.12 \\
*Lengths of gradient & 0.00 & 5.82 & 7.52 & 3.99 & \\
Species-environment correlations & 0.96 & 0.90 & 0.68 & 0.56 & \\
Cumulative percentage variance & & & & & \\
$\quad$ of species data & 11.3 & 19.3 & 24.0 & 27.3 & \\
$\quad$ of species-environment relation: & 40.0 & 68.0 & 84.7 & 96.6 & \\
$\quad$ Sum of all eigenvalues & & & & & 7.12 \\
Sum of all canonical eigenvalues & & & & & 2.02 \\
\hline
\end{tabular}

\begin{tabular}{|c|c|c|c|c|c|}
\hline \multirow[b]{2}{*}{ Axes } & \multicolumn{5}{|c|}{ Antalya Basin } \\
\hline & 1 & 2 & 3 & 4 & Total inertia \\
\hline Eigenvalues & 0.98 & 0.74 & 0.53 & 0.17 & 5.34 \\
\hline *Lengths of gradient & 0.00 & 5.25 & 3.13 & 1.63 & \\
\hline Species-environment correlations & 0.98 & 0.91 & 0.80 & 0.47 & \\
\hline \multicolumn{6}{|l|}{ Cumulative percentage variance } \\
\hline of species data & 18.3 & 32.2 & 42.2 & 45.4 & \\
\hline of species-environment relation: & 39.7 & 69.9 & 91.5 & 98.5 & \\
\hline Sum of all eigenvalues & & & & & 5.34 \\
\hline \multirow[t]{2}{*}{ Sum of all canonical eigenvalues } & & & & & 2.46 \\
\hline & \multicolumn{5}{|c|}{ West Mediterranean Basin } \\
\hline Axes & 1 & 2 & 3 & 4 & Total inertia \\
\hline Eigenvalues & 0.86 & 0.63 & 0.43 & 0.10 & 6.81 \\
\hline${ }^{*}$ Lengths of gradient & 6.34 & 5.07 & 13.6 & 3.22 & \\
\hline Species-environment correlations & 0.97 & 0.88 & 0.78 & 0.50 & \\
\hline \multicolumn{6}{|l|}{ Cumulative percentage variance } \\
\hline of species data & 12.6 & 21.9 & 28.2 & 29.7 & \\
\hline of species-environment relation: & 40.8 & 70.9 & 91.5 & 96.2 & \\
\hline Sum of all eigenvalues & & & & & 6.81 \\
\hline Sum of all canonical eigenvalues & & & & & 2.10 \\
\hline
\end{tabular}




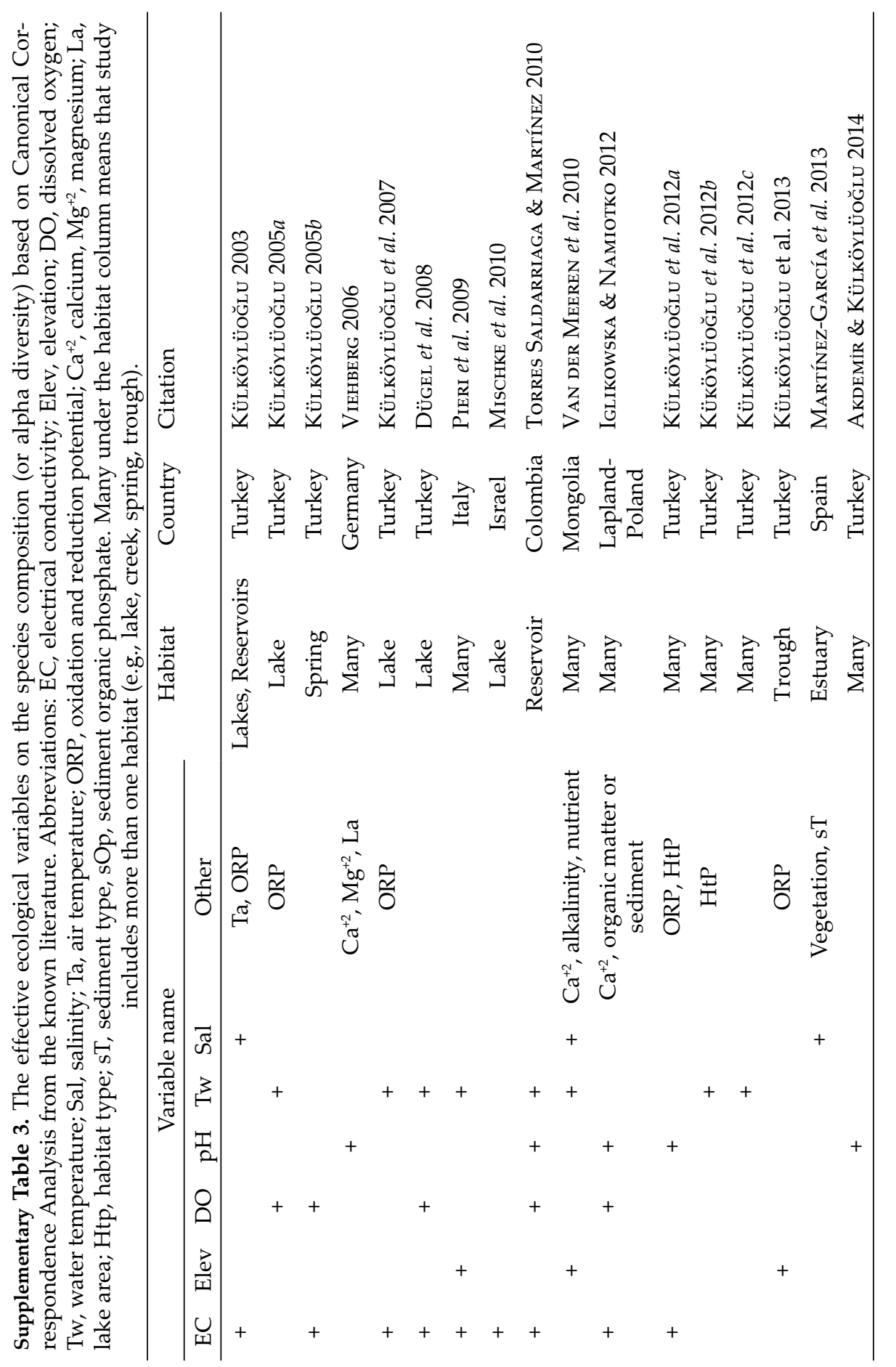

Acta Zool. Acad. Sci. Hung. 65, 2019 


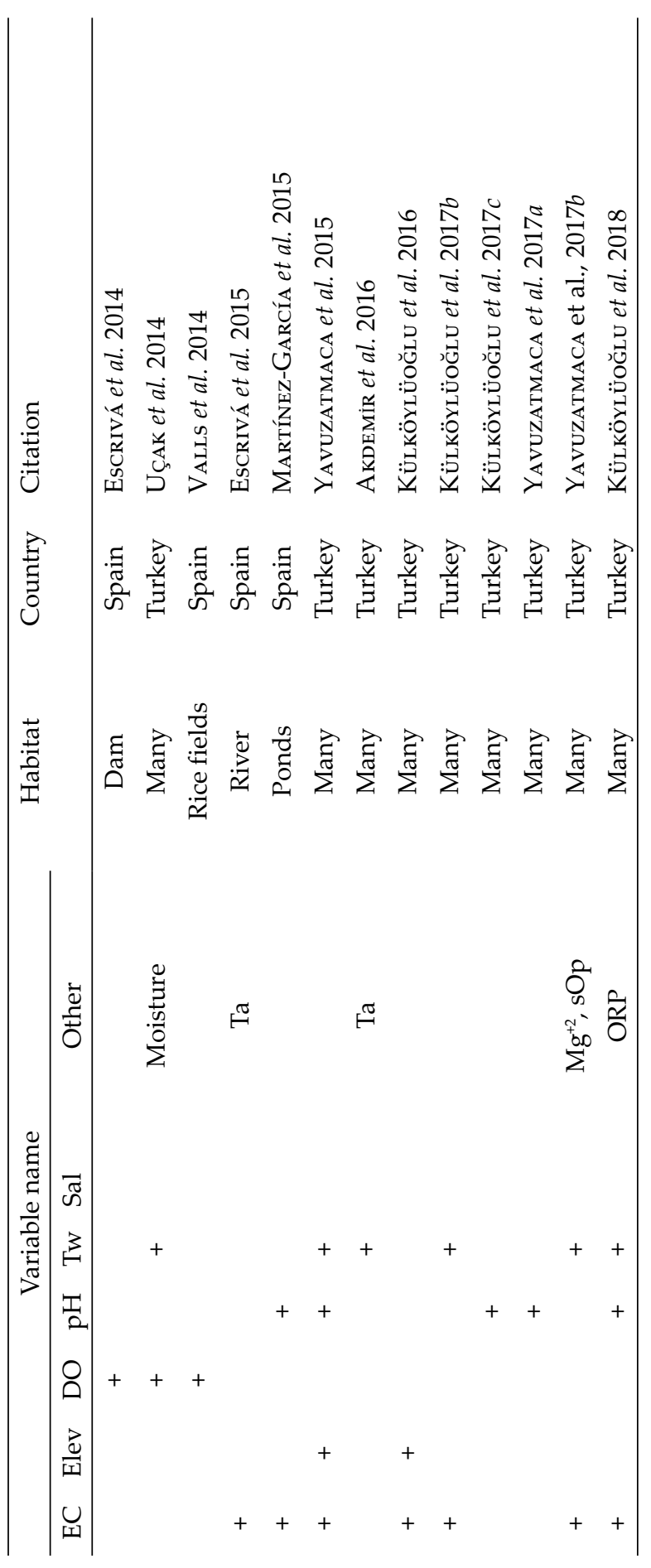

Acta Zool. Acad. Sci. Hung. 65, 2019 


\title{
Contributions to a Manual of Palaearctic Diptera
}

\author{
Edited by L. Papp and B. Darvas \\ Volumes 1-3, Appendix
}

The excellently illustrated volumes of the "Contributions to a Manual of Palaearctic Diptera" morphological, physiological, genetical, ecological and economic up-to-date knowledge of dipterous species (midges and flies), which have significant importance in genetics as model organisms, in plant cultivation as pests or beneficial parasitoids, in animal husbandry and human health as vectors of serious illnesses and which are important for ecosystem function, are treated. Morphological keys to generic level for adults and larvae are provided, which help readers with identification of dipterous pests and parasitoids, while readers in the field of applied dipterology will find suitable environmentally friendly methods against pests or biological control methods.

Volume 1 (published in 2000): 24 chapters of general and applied dipterology, by 31 specialists, on 978 pages with 956 figures on 176 plates. Volume 2 (published in 1997): 38 dipterous family chapters, by 23 specialists, on 592 pages with 1895 figures on 258 plates. Volume 3 (published in 1998): 56 dipterous family chapters, by 32 specialists, on 880 pages with 1773 figures on 294 plates. Appendix (published in 2000): 16 dipterous family chapters, by 19 specialists, on 604 pages with 2134 figures on 207 plates.

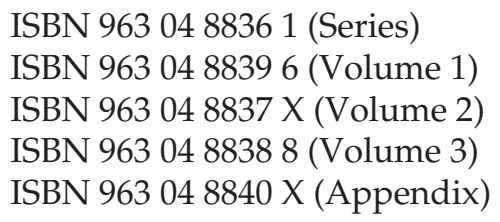

Foundation for the Publicity of the Hungarian Science Publisher: Science Herald, Budapest

Order should be sent to

NEST Foundation, Collegium Budapest Ms Szilvia Zimber, E-mail: szimber@ colbud.hu 